\title{
Development of an ancient shoreline database to reconstruct the Litorina Sea maximum extension and the highest shoreline of the Baltic Sea basin in Finland
}

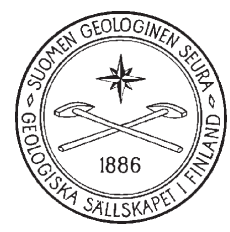

\author{
Antti E.K. Ojala ${ }^{1)^{*}}$, Jukka-Pekka Palmu ${ }^{1)}$, Annika Åberg ${ }^{2)}$, \\ Susanne ÅBerg ${ }^{2)}$ AND Hanna VirkKi ${ }^{1)}$ \\ 1) Geological Survey of Finland, P.O. Box 96, FI-02151 Espoo, Finland \\ 2) Department of Geosciences and Geography, P.O. Box 64, \\ FI-0014 University of Helsinki, Finland
}

\begin{abstract}
An ArcGIS geodatabase called the Ancient Shoreline Database (ASD) was developed for the study and interpretation of ancient shorelines and shoreline displacement information. It was further divided into the Isolation Database (ISD) and Shoreline Landform Database (SLD) based on the characteristics of the available information. In the current study, observations related to the maximum extension of the Litorina Sea and the highest shoreline in Finland were carefully recorded and classified in the ASD. A total of 1625 shoreline observations were stored in the ASD, of which 106 were stratigraphic data points from dated isolation horizons (ISD) and the remaining 1519 were data points representing morphological shoreline observations (SLD). This paper describes the content of the ASD in terms of the variability and reliability of collated data points, but also introduces how modern LiDAR-based digital elevation models were utilized in validating the published observations as well as in interpreting new data points related to ancient shorelines from areas lacking information. The compiled ASD was used to reconstruct the diachronous maximum extension of the Litorina Sea and the highest shoreline of the Baltic Sea basin in Finland.
\end{abstract}

Keywords: data bases, digital terrain models, Baltic Sea, Litorina Sea, raised beaches, highest shoreline, sea-level changes, uplifts, lakes, Holocene, Weichselian, Finland

*Corresponding author e-mail: antti.ojala@gtk.fi

Editorial handling: Joonas Virtasalo 


\section{Introduction}

Glacial unloading and isostatic post-glacial rebound are well-known phenomena in the Fennoscandian shield area, where the Earth's crust has been continuously rising since the Weichselian glacial maximum around 20-22 ka ago (De Geer, 1890; Ramsay, 1924; Kakkuri, 2012). This rising is still ongoing and centred around the northern part of the Gulf of Bothnia, where the current rate of uplift is about $1 \mathrm{~cm} \mathrm{a}^{-1}$ (Fig. 1). As a consequence, the shoreline of the Baltic Sea basin (BSB) has been constantly displaced and even today the land area of the Finnish coastline is annually increasing by ca. 700 ha due to the slowly proceeding regression (Kakkuri, 2012). Combined with the rising of the global sea level (eustacy) and geoidal changes since the Weichselian glaciation (e.g. Fairbanks, 1989), the Baltic Sea basin has undergone significant changes as reviewed by Björck (1995), Donner (1995) and Andrén et al. (2000), among others. The history of the BSB is important from the viewpoint of the sedimentary environment because the formation of many types of superficial deposits, such as glaciofluvial deltas and sandurs, beach ridges and stone belts, fine-grained silt and clay, which have formed during and/or after deglaciation, depends on the activity of melt waters streaming in front of the retreating continental ice sheet and the water depth and shoreline placement of the BSB during deposition. Together, they have affected the appearance Late Quaternary landscapes and sedimentary deposits in Finland.

There are several important reasons why the ancient shorelines should be studied and carefully recorded in the deglaciated terrain of Finland. Among these is the history of the BSB, as well as the evolution of the great lakes in Finland and their main palaeohydrological changes (e.g. Saarnisto, 1970; Eronen, 1992; Seppä et al., 2012). The relative altitude of the shoreline in the past also strikingly contributed to the genesis of the superficial deposits in Finland, which is why defining the boundary between subaquatic and supra-aquatic areas, as well as shoreline displacement over time, is important when mapping Quaternary deposits and searching for raw materials such as gravel, sand or clay for industry and construction (Ikävalko et al., 2011; Palmu, 2011; Vuori et al., 2011). Information on the relative sea level changes in the past also allows the location of prehistoric dwelling sites to be determined (e.g. Ukkonen, 2002). In addition, many other applications benefit from information on shoreline displacement, such as approximation of the past and the future sea level scenarios or investigating neotectonic deformations of the Earth's crust (e.g. Mäkiaho, 2007).

An abundance of morphological and stratigraphical information related ancient shoreline displacement since the Weichselian glaciation is available from all around Finland (e.g. Ramsay, 1924; Glückert, 1976; Saarnisto, 1982; Ristaniemi, 1987; Eronen, 1992). However, this information is scattered and very heterogeneous, and hence difficult to utilize in geographic information systems. In addition, no serious published attempts have been made to carefully classify all the available information in a way that could enable it to be stored in a database accessible to multiple users through a web interface. It is also likely that shoreline reconstructions published in the past (e.g. Eronen \& Haila, 1992; Tikkanen \& Oksanen, 2002; Johansson, 2005) are, in fact, based on different sets of data points, which in many cases are untraceable afterwards. Hence, their critical review, the use of the available data, and the production of new reconstructions and cartographic layouts including additional information is virtually impossible.

To improve our general understanding of the data available on shoreline displacement in Finland and to systematically classify this information, we compiled an ArcGIS geodatabase called the Ancient Shoreline Database (ASD). A similar type of approach has earlier been adopted at least in Estonia (Vassiljev et al., 2005; Rosentau, 2006) and Sweden (Svensson, 1989; Jakobsson et al., 2007). The present study aimed at formulating a suitable geodatabase that could be used to systematically collect and classify all relevant information needed in studies on ancient shorelines in the BSB region. In the first stage, we concentrated on collecting diachronous information related to the highest 


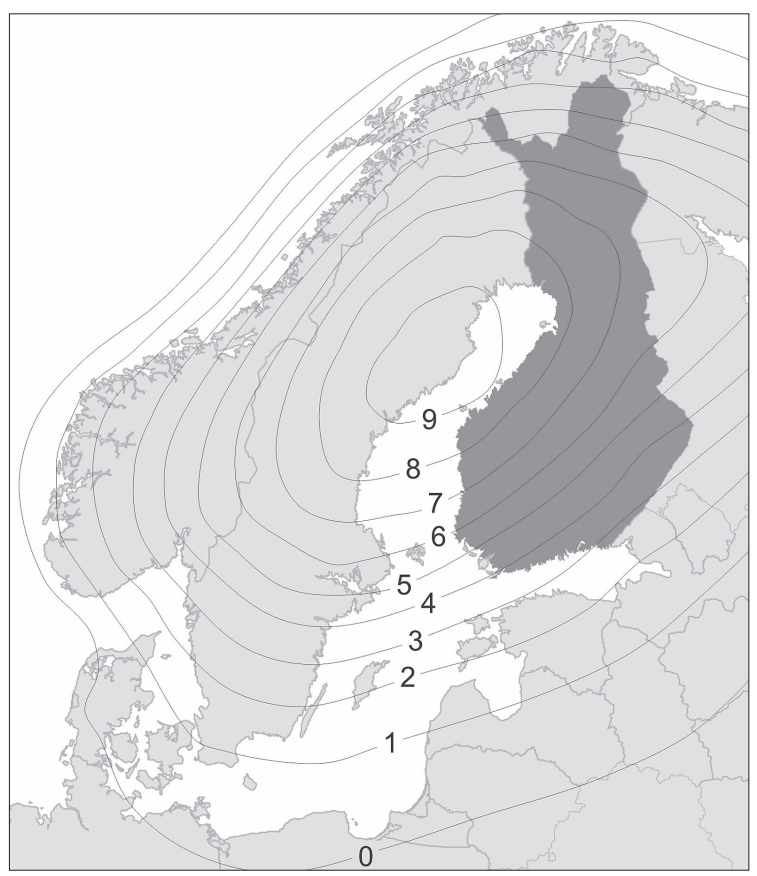

Fig. 1. The land uplift isobases (relative to mean sea level) of the Fennoscandian shield in $\mathrm{mm}$ per year. (Modified from Kakkuri, 2012).

shoreline and the maximum extension of the Litorina Sea stage in Finland. With the highest shoreline we mean the boundary between supraaquatic and subaquatic areas. The content of the ASD is discussed in the present paper. The paper also introduces the use of an airborne LiDAR (light detection and ranging) digital elevation model (DEM) in validating published information, as well as producing additional shoreline data points in areas that lack information. The final aim of this study is to reconstruct the diachronous maximum extension of the Litorina Sea and the highest shoreline of the Baltic Sea basin in Finland. The resulting maps are meant to be updated versions of the ancient shoreline reconstructions by Eronen \& Haila (1992).

\section{Methods}

\subsection{Compilation of the Ancient Shoreline Database (ASD)}

The available and published information on ancient shorelines in Finland was compiled in an ArcGIS geodatabase called the Ancient Shoreline Database (ASD). In fact, the ASD is comprised of two separate databases, the Isolation Database (ISD) and the Shoreline Landform Database (SLD), of which the former is for dated peat and gyttja of isolated lake basins and mires, and the latter for different types of landforms representing ancient shorelines.

The basic structure of the ISD and SLD is the same (Appendix 1). They both contain site-specific metadata, such as the running ID number and the ID number from the original publication, the site name, locality, principal investigator, study year and the original reference. The coordinates for each site were determined according to the Finnish uniform coordinate system, but original coordinates from published data points were also included when available. Longitude and latitude information reported in original publications was checked from topographic datasets of the National Land Survey of Finland, and notes were taken if any coordinate readjustment was conducted or conversion of the coordinate system completed during data validation and storage. For example, some of the published data points only included the site name, locality and altitude. In such cases, the coordinates were determined and the description of the coordinate readjustment in the ASD was marked as "missing coordinates" (see Appendix 1).

For the ISD, the site type was classified as lake, mire or other, and the current surface altitude (m a.s.l.) and threshold altitude of isolation ( $\mathrm{m}$ a.s.l.) was recorded in the database. In each case, information from radiocarbon dating of the isolation horizon was also recorded as the original ${ }^{14} \mathrm{C}$ dating codes and determination method, and subsequently all radiocarbon ages were calibrated using the CALIB 6.0 program that is based on IntCal09 terrestrial radiocarbon age calibration data set (Reimer et al., 2009).

For the SLD, the landform type was classified as delta surface, sandur-delta, beach ridge, delta and beach ridge, cliff and shore terrace, stone belt, lake rampart, moraine calotte and washed hillside, outlet channel and delta surface of a local ice lake, esker top, or unclassified. The mean shoreline altitude was recorded for each data site, but minimum and 
maximum values were also noted to characterize their internal dispersion and to reduce subjectivity of classification. Moreover, as clearly pointed out by Saarnisto (1981), the height of a washing limit in moraine calottes, for example, depends on the exposition of the study location and may thus vary by up to 3-4 meters according to Fromm (1965). The same also applies to many other types of shoreline landforms. A note was also included regarding whether the altitude was readjusted from the original reference due, for example, to gain more detailed information or to correct the original readings using better DEMs. In particular, some of the oldest sites were characterized by inadequate altitudes. The site-specific altitudes (m a.s.l.) were checked from the airborne LiDAR DEM data, but also from $10-\mathrm{m}$ or $25-\mathrm{m}$ grid elevation models at locations where LiDAR DEM data were not available. The source for altitude revision was recorded in the ASD.

We also recorded the shoreline stage index as proposed by the original investigator and as interpreted in the present study (Appendix 1). In order to increase the usability of the present ancient shoreline database (ASD), we systematically classified the data into five reliability classes, where the class 1 represents the most certain and the class 5 the most uncertain observation. The reliability classifications were defined separately for SLD and ISD as their potential uncertainty factors were clearly different. The characterization of both classifications is presented in Table 1 .

\subsection{Shoreline reconstructions}

The ancient shoreline reconstructions of the Litorina Sea maximum extension and the highest shoreline presented here are based on interpolation of the water level surfaces within the range of selected data points recorded in the ASD. The interpolation method used was a triangulated irregular network (TIN). The selection of TIN method was based on e.g. Burrough \& McDonnell (1998), Oksanen (1998), Leverington et al. (2002) and Mäkiaho (2007), who noted that the TIN interpolation works best when creating digital topography from
Table 1. Description of the reliability classification of data points included in the isolation database (ISD) and the shoreline landform database (SLD) of the ASD. Each data point was given a class number ( 1 to 5 ) according to its characteristics.

\section{Shoreline Landform Database (SLD)}

Class 1: Confident observation with minor $(<4 \mathrm{~m})$ fluctuation in altitude

Class 2: Confident observation with more significant (> $4 \mathrm{~m}$ ) fluctuation in altitude

Class 3: Published observation with uncertainties in altitude (as validated from 2 or $10 \mathrm{~m}$ grid DEMs)

Class 4: Published observation with uncertainties in e.g. location or recognition of landform on maps

Class 5: Uncertain or non-validated site and/or observation

\section{Isolation Database (ISD)}

Class 1: Confident observation dated using modern methods (e.g. AMS ${ }^{14} \mathrm{C}$ ) and with only a minor margin of dating error

Class 2: Confident observation dated using modern methods (e.g. AMS ${ }^{14} \mathrm{C}$ ), but with significant margin of error in dating or uncertain isolation threshold altitude

Class 3: A well known published observation, but with significant uncertainties in location or isolation threshold, or contains prominent uncertainties or ambiguities in dating

Class 4: Less significant observation with uncertain location, altitude or other ambiguities related to e.g. sediment stratigraphy

Class 5: Uncertain or non-validated site and/or observation

irregularly spaced data points with variable elevation. In addition, Oksanen (1998) previously tested that TIN model and trend surface interpolations are the most suitable methods to interpolate the geographically varying level of the ancient shorelines of the Baltic Sea basin in Finland. A group of dummy points (i.e. dummies) was also established in order to extend the data point coverage to cover the whole of Finland (Åberg, 2013a; Åberg, 2013b). 
The values of the dummies were estimated based the isobases of Fromm (1965), Eronen (1974), Eronen \& Haila (1992), Glückert (1976) and Glückert et al. (1993).

The reliability classification of data points was applied in TIN model constructions to make them as accurate as possible. The unsecured data points with, for instance, incorrect elevations or unverified locations were excluded from TIN calculations. TIN models were also tuned on a step-by-step basis by removing incongruous data points that created apparent local anomalies. The completed TIN surface models were then converted into raster formats and the ancient shoreline distributions were calculated by subtracting the raster data from digital elevation model of a cell size of 10 m (DEM 10). The cell size of the final reconstructions were also $10 \mathrm{~m}$ and indicative for the maximum extension of the Litorina Sea and the boundary between suband supra-aquatic areas (i.e. the highest shoreline) as well as the relative depth and altitude around them at the time of shoreline developments.

\section{Results and discussions}

\subsection{Content of the Ancient Shoreline Database (ASD)}

The distribution of the 1625 data points thus far stored in the ASD is presented in Fig. 2. As the focus of this work was on the maximum extension of the Litorina Sea and the highest shoreline, they respectively represent 686 and 790 data points in the ASD. Of the remaining data points, 149 represent local ice lakes, as suggested by the original author or/and interpreted in the present study. In addition, a few data points that represent ancient lakes, drained lakes, or that could not be determined are also included in the SLD. Most of the data points that were collated to represent the highest shoreline are landforms of different types (SLD), and only a few are stored in the Isolation Database (ISD). This is because sediment stratigraphical studies aimed at determining the highest shoreline in Finland are scarce, and only a few publications exist with observations related to isolation horizons near the supra-aquatic limit (Ristaniemi, 1987). In the Litorina Sea study, 102 data points represent the isolation threshold level and are stored in the ISD, whereas the great majority (584) are in the SLD. It should be noted that only those stratigraphic studies of the isolated basins that were considered to represent the maximum Litorina Sea extension, or being very close to that, were accepted and included into the ISD in the present study. Thus, a large amount of available stratigraphic information on different stages of the Litorina Sea, as well as shoreline displacement information during the preceding Lake Ancylus and Yoldia Sea stages, was omitted (e.g. Ristaniemi \& Glückert, 1988; Miettinen et al., 1999; Ojala et al., 2005).

With the highest shoreline, ca. $92 \%$ of the information in the ASD comprises published data points that were verified from maps and digital elevation models in the present study. The remaining ca. $8 \%$ are either new data points interpreted in the present study by the authors (ca. $4 \%$ ) or are based on personal communications during the data collection (ca. $4 \%$ ). Some of the key studies that were used as a reference material included Sauramo (1928), Ramsay (1931), Hellaakoski (1934), Glückert (1977), Kurimo (1979), Saarnisto (1981; 1982), Ristaniemi (1987) and Mäkinen et al. (2011). According to the classification of the landform types, ca. $50 \%$ of the data points were classified as moraine calotte and washed hillside. They were formed at locations where the slopes of hills were washed by waves and reformed by winter ice into cobble and boulder belts and embankments below washout limits, whereas hilltops remained covered by unwashed till. Such raised ancient shoreline formations are typically found in the northern part of Finland, where they lie at an altitude of up to $220 \mathrm{~m}$ above the present sea level (e.g. Saarnisto, 1981; Johansson \& Kujansuu, 2005). Delta surface and stone belt landform types respectively occur in $18 \%$ and $11 \%$ of the cases. Cliff and shore terraces comprise $8 \%$ of data points, and the remaining types occur less frequently ( $\leq 5 \%$ of the cases). Numerous delta surfaces and shore terraces have developed in eskers and other glaciofluvial formations where wave activity and meltwater streams from retreating ice 


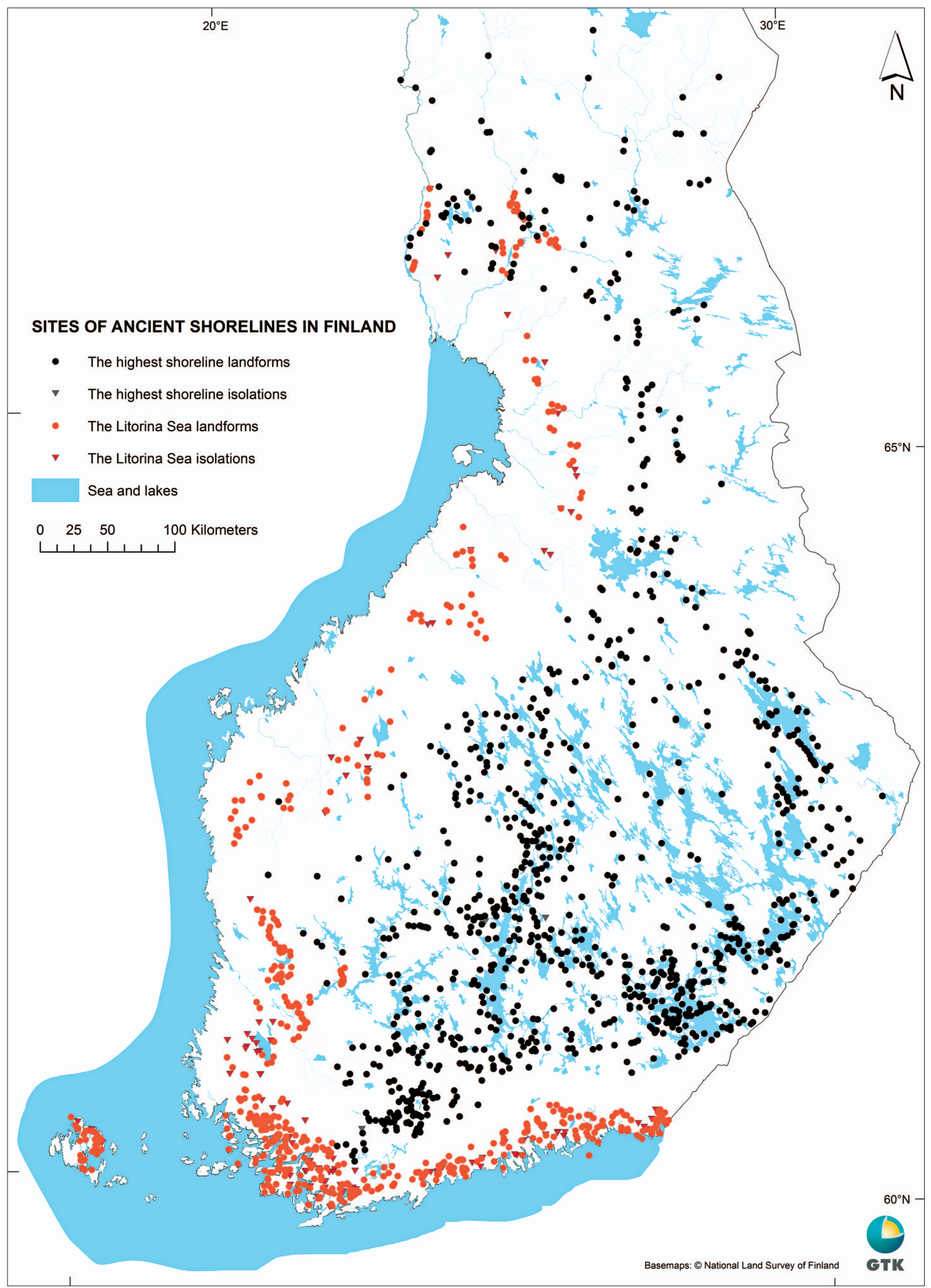

Fig. 2. Distribution of the recorded data points in the Ancient Shoreline Database (ASD). Basemap @ the National Land Survey of Finland. 
sheet margin deposited and reworked sandy material. Data points classified as glaciofluvial deltas in the ASD appear particularly in the Salpausselkä zone as delta-moraine complexes formed in the Baltic Ice Lake and the subsequent Yoldia Sea (e.g. Sauramo, 1928; Saarnisto, 1982). In turn, shoreline landforms developed in eskers are more evenly distributed throughout Finland. In some localities, differentiation of deltaic formations developed in the BSB from those developed at the water level of local ice lakes was problematic, because they lie at similar altitude and local ice-dammed lakes often appear as sequence of short-lived events in front of the retreating ice sheet (Saarnisto, 1981). As a consequence, a large number of shoreline landform data points related to local ice lakes were stored in the SLD during the collection of the highest shoreline data. It is known, for example, that an ice-dammed basin called the Sääminki Ice Lake existed in the Saimaa region during the deglaciation (e.g. Saarnisto, 1970; Hakulinen, 2009).

Furthermore, a number of extramarginal deltas formed in larger ice-dammed lakes exist in the northern part of Finland, but based on previous reports by Eronen \& Haila (1992) and Johansson (2005) they were largely avoided during data collection (Fig. 2). One important aspect with the highest shoreline observations in the ASD is that $63 \%$ and $14 \%$ of the cases were respectively classified as confident observations with minor (class 1) or moderate (class 2) fluctuation in the altitude determination. In $19 \%$ of the cases there was uncertainty in the location (class 4), and very few observations fell into class 5 . However, some of the reliable class 1 and 2 observations were excluded from the highest shoreline reconstructions, because they were considered to represent local ice lakes or other incongruous altitude anomalies.

Regarding the maximum extension of the Litorina Sea, ca. $62 \%$ of the information in the ASD consist of published data points, of which the great majority were verified from maps and digital elevation models in the present study. Altogether, $36 \%$ of the cases, i.e. a total of 247 new observations, were completed by the authors in the present study using airborne LiDAR DEM, topographic datasets and orthographic photos of the National Land Survey of Finland, as well as digital maps of superficial deposits by the Geological Survey of Finland (see next chapter for an example). The remaining ca. $2 \%$ of the data points are based on personal communications during data collection. Some of the key studies that were used as reference material included Rudeberg (1925), Hyyppä (1937), Glückert (1976; 1978; 1989), Ristaniemi \& Glückert (1988), Eronen et al. (1993; 2001) and Miettinen et al. (1999). Of the observations included in the SLD, stone belts (45\%), cliff and shore terraces $(26 \%)$, and beach ridges $(13 \%)$ were the most common morphological features to represent the maximum extension of the Litorina Sea. In general, these shoreline landforms are distinctive morphological features in the south and SW coastal area of Finland, where the eustatic sea level rise equalled or exceeded the isostatic uplift, resulting in a standstill or subtle rise in the relative shore level (the Litorina transgression) at around 9000-7000 years BP (e.g. Ristaniemi \& Glückert, 1988; Glückert, 1989; Eronen, 1992). Further north, on the coast of the Gulf of Bothnia, morphological shoreline landform features representing the maximum Litorina Sea extension are less prominent, and sediment stratigraphical observations in the ISD consequently form a very important source of information. In some cases, it was difficult to determine the shore landform type for those representing the Litorina Sea stage, which is why the "other" category includes $13 \%$ of the cases. In $54 \%$ and $8 \%$ of the cases, observations were respectively categorised as class 1 and 2 in the reliability classification. In surprisingly many cases $(20 \%)$ there were uncertainties in site location, which is why many of the published data points fell into class 4 .

A more detailed description of the data points in the ASD, including their coordinate and/or altitude corrections, geographical coverage, typical case-wise examples and shoreline stage index, is presented and discussed in Åberg (2013a) and Åberg (2013b). 


\subsection{The use of LiDAR DEM in shoreline identification}

The ever increasing use of LiDAR DEMs in surveying and mapping of the Earth's surface has raised possibilities to investigate geological formations very precisely, accurately, and with a remarkably high resolution (e.g. Meng et al., 2010; Oksanen \& Sarjakoski, 2006). Among the advantages of LiDAR-based digital elevations models, is that the data can be seamlessly and rapidly collected and processed for a wide range of different purposes with high quality and a reduced cost per unit area (e.g. Streutker \& Glenn, 2006; Fleeger et al., 2011; Chen et al., 2012). In geology, LiDAR data have been used to conduct high-precision facies characterization and 3D modelling of stratigraphic sites (e.g. Bellian et al., 2005), monitoring and modelling of landslide hazards (e.g. Schulz, 2007; Haneberg et al., 2009), measuring the strandlines (Yang \& Teller, 2012), and mapping of superficial geology (e.g. Nenonen et al., 2010; Fleeger et al., 2011; Dowling et al., 2013), among many other applications.

Here we present three examples of how the LiDAR DEMs can be utilized in surveying and mapping ancient shoreline landforms in Finland. For this purpose, the LiDAR cloud point data provided by the National Land Survey of Finland were processed with ArcGIS (C ESRI) software to construct a 2-m grid DEM. A feature dataset was first created from cloud point data, which was used to construct a terrain and then processed to a digital elevation model of the bedrock and superficial deposits lying upon it (J. Vanne \& M. Larronmaa, personal communication 2013). Next, the produced DEM was processed with a multi-directional oblique-weighted hillshade effect (primary illumination direction 325) and optional vertical exaggeration of 6 times (Jenness, 2013). This information was then combined with digital maps of superficial deposits (1:20 000 and 1:50 000) provided by the Geological Survey of Finland and corrected aerial photographs (orthophoto) of the National Land Survey of Finland when validating the published information and interpreting new data points and observations in the SLD.

The first example is from Lohiniva, Rovanie$\mathrm{mi}$, in the valley of the River Ounasjoki in Northern Finland, where the highest shoreline was formed during the Ancylus Lake stage (Fig. 3). Saarnisto (1981) described the appearance of the highest shoreline (a moraine calotte) on the western slope of Mettisvaara at an altitude of about $185(-190)$ m a.s.l. (ID_GTK: 6911 in the ASD). The same

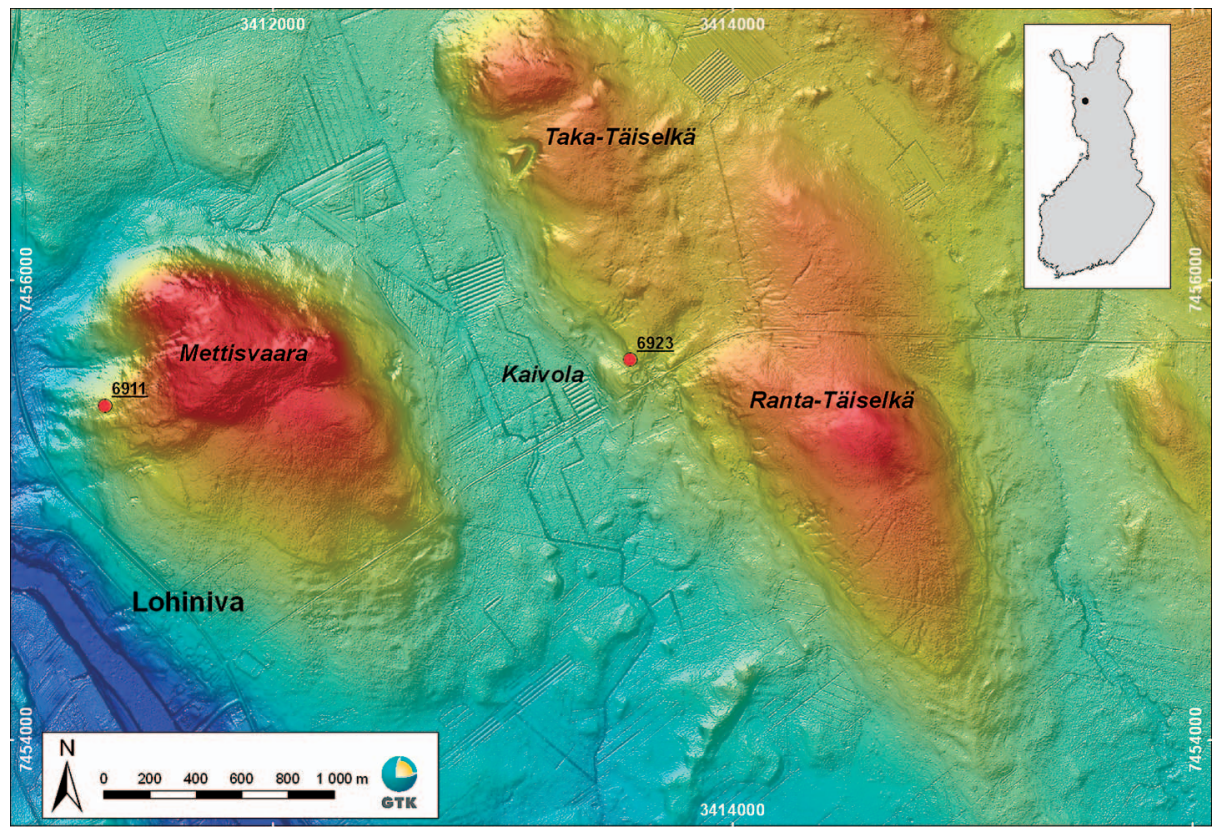

Fig. 3. A LiDAR-based digital elevation model of the Ranta-Täiselkä beach ridge (ID_GTK: 6923) representing the highest shoreline of the BSB at $185 \mathrm{~m}$ a.s.l. located about 90 km N/NW from Rovaniemi. Basemap and LiDAR (c) the National Land Survey of Finland. 
locality and altitude is also characterized by other distinctive and extensive depositional and erosional features that are related to the highest coastline as indicated by processed LiDAR DEMs. A continuous beach ridge can be observed on the south and SE slopes of Mettisvaara and Ranta-Täiselkä hills, and it lies at an altitude of about $185 \mathrm{~m}$ a.s.l. (Fig. 3). The same beach ridge (ID_GTK: 6923) also continues on the SW slope of Taka-Täiselkä and Ranta-Täiselkä, where it is cut off by small-scale plains near Kaivola, which probably represent waterlain deposits very close to the highest shoreline in this region. The curved erosional feature seen west of Taka-Täiselkä hill may represent an outflow drainage channel that was formed in front of the continental ice sheet during deglaciation. The base of this outlet channel lies at $186 \mathrm{~m}$ a.s.l.

The second example in Figure 4 is from the Suurikangas sandur-delta in Tohmajärvi, eastern Finland. It represents an outwash plain formed by melt-water deposition in front of the retreating ice sheet. The highest shoreline here relates to the Baltic Ice Lake stage B III in the Second Salpausselkä region prior to its rapid lowering $(25 \mathrm{~m})$ to the Yoldia Sea level (Y I) at ca. 11,600 years BP (Andrén et al., 2000). The highest shoreline in this site (ID_GTK: 6926) lies at $119.9 \mathrm{~m}$ a.s.l. and was interpreted in the present study to an altitude, where braided meltwater systems (sandur) shift to a deltaic type of formation in front of the retreating glacier. The LiDAR DEM indicates that the outburst floods in the Suurikangas region have been orientated to NE, east and SE directions, and all directions reveal similar altitudes (119-121 m a.s.l.) for the determination of the sandur characteristics. The interpretation of the highest shoreline here is supported by the observation of Ramsay (1931) from Hiilikangas, Tohmajärvi, where he described a moraine calotte and washed hillside (ID_GTK: 6882) at an altitude of $121 \mathrm{~m}$ a.s.l.

The third example is from the Kvigos beach ridge (ID_GTK: 9537) in Raasepori, SW Finland, which was formed on pre-crag drumlin during the maximum extension of the Litorina Sea (Fig. 5). The beach ridge was first described by Rudeberg (1925) and lies at an altitude of $44.6 \mathrm{~m}$ a.s.l. As seen from the hillshaded LiDAR DEM, this beach ridge is a distinctive and extensive feature on the western slope of Malarberget hill, with its altitude fluctuating between 43.8 and $44.7 \mathrm{~m}$ a.s.l. (Fig. 5). The insert in Figure 5 indicates that is it a clear ridge, about $1 \mathrm{~m}$ in height, that runs along the precrag formation and mainly parallel to the ancient shoreline. It was probably deposited by waves during

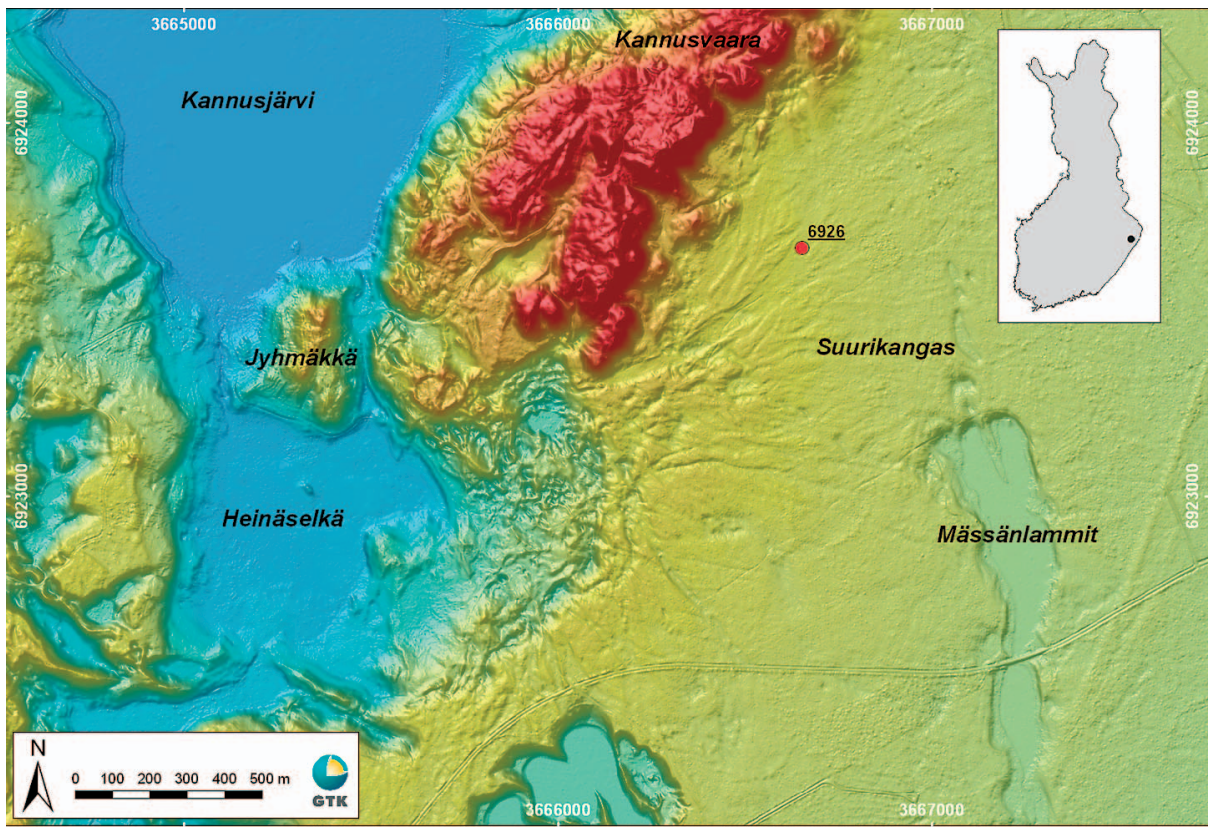

Fig. 4. The Suurikangas sandur-delta in Tohmajärvi, eastern Finland, was deposited in frontal of the Lake District Ice Lobe in the Salpauselkä region. The interpreted highest shoreline (ID_ GTK 6926) lies at 119.9 $\mathrm{m}$ a.s.l. Basemap and LiDAR (c) the National Land Survey of Finland. 


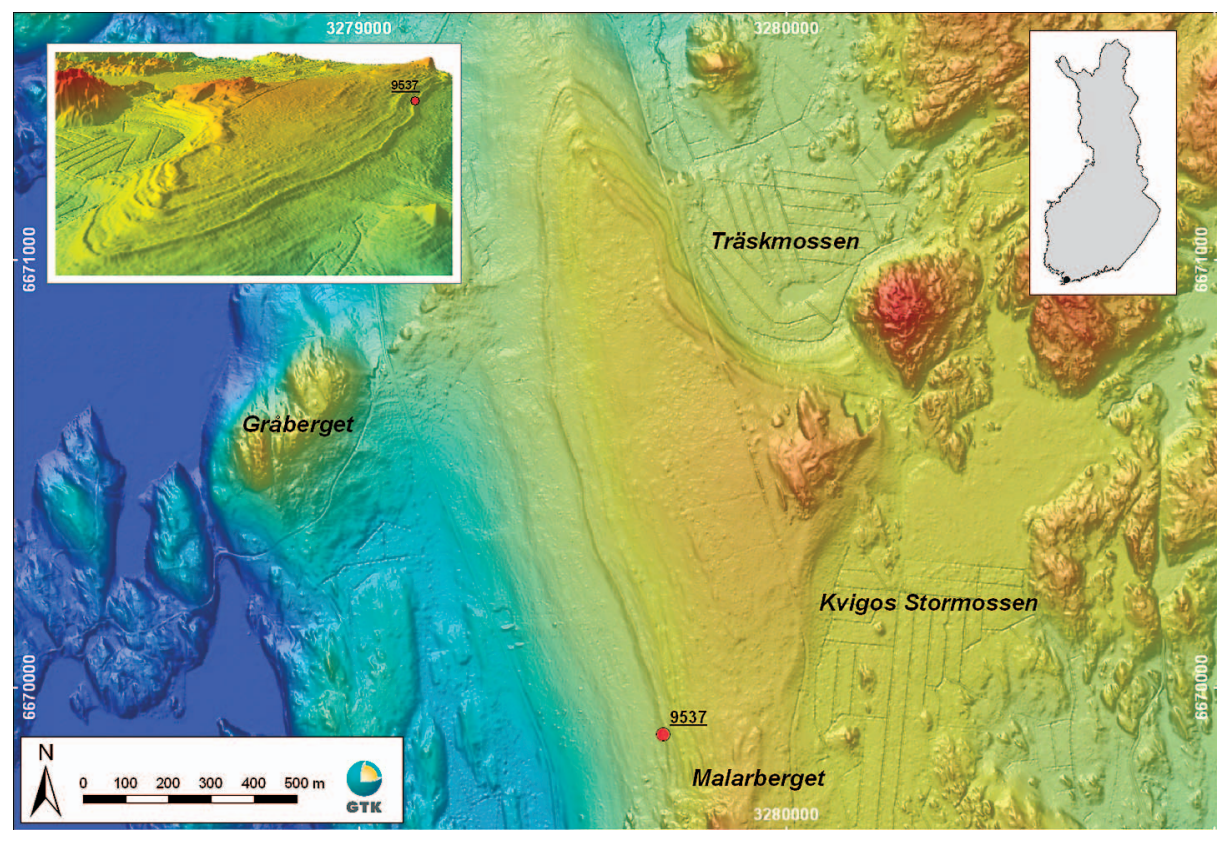

Fig. 5. The Kvigos beach ridge (ID_GTK: 9537) at $44.6 \mathrm{~m}$ a.s.l., located about $30 \mathrm{~km}$ west from Raasepori, determines the highest altitude of the Litorina Sea in SW Finland. The insert in the upper left corner presents a 3D LiDAR DEM visualization of the shoreline formation and was processed using ArcScene 9.3.1. Basemap and LiDAR (c) the National Land Survey of Finland. the Litorina Sea transgression between 9000-7000 years BP (Glückert, 1976, 1977; Eronen, 1992). In addition to the Litorina Sea shoreline, a set of higher altitude morphological shorelines appears on the NE side of Malarberget hill between ca. 47-53 $\mathrm{m}$ a.s.l. These older shorelines appear on the protected slopes of the hill facing Träskmossen peat bog and are probably related to earlier Ancylus Lake stages.

\subsection{Ancient shoreline reconstructions}

\subsubsection{Diachronous maximum extension of the Litorina Sea in Finland}

The best data points with the highest reliability classes, class 1 and class 2 , were selected to construct a map of the diachronous maximum extension of the Litorina Sea at around 7000-9000 years BP. In addition, a selection of several lower ranked data points (classes 3, 4 and 5) were chosen to extend the geographical coverage of data points and thereby improve the modelling results. Most of the lower ranked data points used in the modelling are from the Åland area. This is because of a lack of LiDAR and $10 \mathrm{~m}$ digital elevation models at the time when the points were created. Except for the Åland area, most of the lower ranked points in classes 5, 4 and 3 were left out of the modelling.

The finally completed TIN model included 397 shoreline landform observations and 16 isolation observations from the ASD. In addition, 38 dummies were generated for modelling purposes. Much of the observations (173 data points) were based on literature sources, but 224 new landform shoreline observations were also included in the TIN model. They were recorded in the present study and based on LiDAR DEMs (cell size of $2 \mathrm{~m}$ ), a topographic dataset and orthographic photos provided by the National Land Survey of Finland, as well as digital maps of superficial deposits by the Geological Survey of Finland. Published data points were mainly from SW Finland (e.g. Rudeberg, 1925; Aurola, 1938; Glückert, 1976; Eronen et al., 1993) and southern Finland (Aario, 1935; Ristaniemi \& Glückert, 1988), but there were also some from Lapland (Eronen, 1974), coastal areas of the Gulf of Finland (Glückert, 1989; Glückert et al., 1993; Miettinen et al., 1999) and Åland (Glückert, 1978). Only a few published data points were available from the Virolahti and Hamina area in SE Finland (e.g. Hyyppä, 1937; Miettinen, 2002), but most of the new observations were located in that area. Many new data points with shoreline landforms were also 
generated in the coastal area of the Gulf of Finland and the Rovaniemi area in the present study. The data points selected for the present reconstruction were marked in the ASD to provide a possibility to update the interpolation maps and produce higher resolution models in geographically restricted areas, but also to allow a critical review of the present results.

The presently reconstructed map of the diachronous maximum extension of the Litorina Sea (Fig. 6) is very similar to that of the previous version by Eronen \& Haila (1992). However, it is much

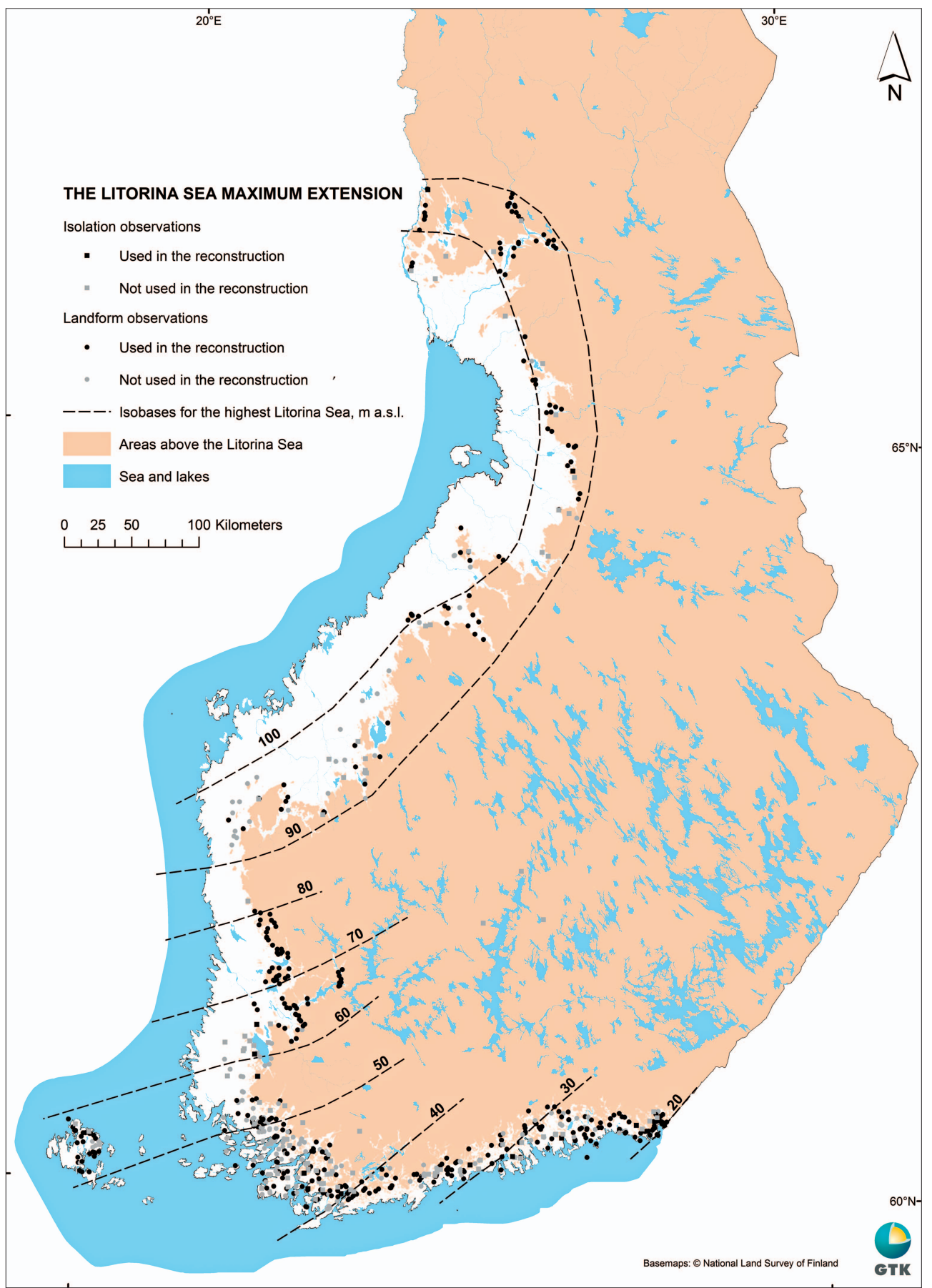

Fig. 6. The diachronous maximum extension and isobases ( $m$ a.s.l.) for the highest Litorina Sea in Finland. The cell size used in modeling for this map was $10 \mathrm{~m}$. Basemap (c) the National Land Survey of Finland. 
more detailed than the previous version, mainly because it was calculated with a relatively small cell size of $10 \mathrm{~m}$. It is by far the most detailed reconstruction of the diachronous maximum extension of the Litorina Sea in Finland. The Litorina Sea covered significant areas in southern, SW and western Finland during its maximum extension at 7000-9000 years BP. In southern Finland, the highest Litorina Sea shoreline is located between 20 and $40 \mathrm{~m}$ above the present day sea level (a.s.l.), whereas in the Turku area in SW Finland it lies at $45-52 \mathrm{~m}$ a.s.l. Further north, along the coast of the Baltic Sea, the altitude of the highest shoreline of the Litorina Sea increases to $80 \mathrm{~m}$ a.s.l. near Pori and to $95 \mathrm{~m}$ a.s.l. in the coastal area of Vaasa. The highest relative shoreline of the Litorina Sea in Finland is found in the vicinity of Ylitornio, where it appears some $108.4 \mathrm{~m}$ a.s.l. This is also one of the recent observations of the highest Litorina shoreline, and it is located on the hillside of Huitaperi (Åberg, 2013b).

\subsubsection{The highest shoreline of the Baltic Sea basin in Finland}

For the highest shoreline, the interpolated TIN model was constructed using data points with reliability classes 1 to 4 in the ASD. Class 5 observations were excluded from the model because they included unsecured data points with, for instance, incorrect elevations in DEMs and missing locations. Data points of class 4 were included in the interpolation because many of them clearly enhanced the quality of the TIN model, even though their original location was uncertain (i.e. a location error of more than $300 \mathrm{~m}$ in radius). Shoreline observations of local ice lakes and ancient lakes were not included in the TIN model, because they do not a have direct connection to the diachronous shoreline of the Baltic Sea basin. In addition, scattered data points were removed from the final TIN model because they caused clear problems and peculiar anomalies in TIN surfaces.

Altogether, 732 of 939 shoreline observations in the ADS were selected and used in the present interpolation. Of the selected observations, 669 data points were taken from different published (e.g. Ramsay, 1931; Hellaakoski, 1934; Glückert, 1977; Ristaniemi, 1987; Saarnisto, 1981) and nonpublished sources, 51 new data points were collected in personal discussions during data gathering and 12 new data points were interpreted during the present study by Åberg (2013a) using DEMs and geological information. A selection of data points used in the present reconstruction was marked in the ASD. Altogether, 69 dummies with altitude and location information were created to enhance the interpolation and cover the whole of Finland (Åberg, 2013a). The location and elevation of the dummies were estimated using maps and isobases by Eronen \& Haila (1992) and Fromm (1965). An additional challenge was that inside the Second Salpausselkä the surface of the Baltic Ice Lake suddenly dropped by $25(-28) \mathrm{m}$ to the water level of the subsequent Yoldia Sea stage (e.g. Saarnisto, 1982). Therefore, additional interpreted data points from delta surfaces representing both water levels, as well as a portion of dummy points, were positioned in the Salpauselkä zone in order to enhance the quality of the TIN model in this region.

The highest shoreline is diachronous because of the duration of deglaciation (ca. 13 000-10 000 cal BP) and the varying land uplift in Finland (Eronen \& Haila, 1992). Therefore, the highest shoreline morphological features lie at a higher altitude in western Finland than in eastern parts of the country. Another general characteristic is that in the Second Salpausselkä region and south of it the highest shoreline landforms have developed to the level of the Baltic Ice Lake (13 000-11 600 years $\mathrm{BP})$, whereas north of the Second Salpausselkä they were formed during the Yoldia Sea and Ancylus Lake stages (11 600-9 000 years BP) (e.g. Andrén et al., 2000).

The present reconstruction of the highest shoreline in Finland (Fig.7) shows that the main features are very similar to those in the map by Eronen \& Haila (1992). However, the new reconstruction is significantly more detailed, which is probably due to the better spatial resolution and DEM, but also because of the modern GIS-based analysis. For example, the boundary between supra-aquatic and 


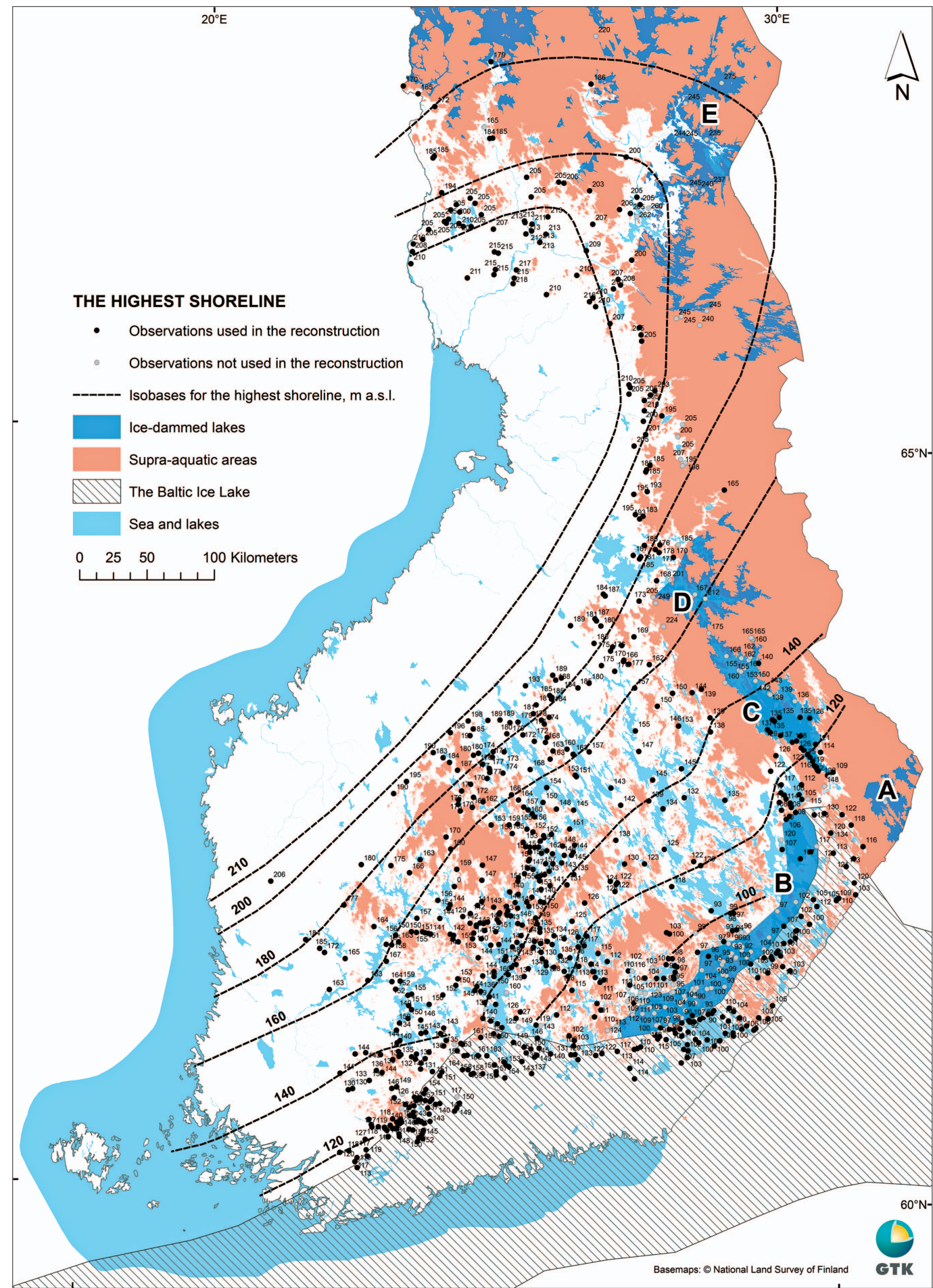

Fig. 7. The highest shoreline of the Baltic Sea basin and isobases ( $m$ a.s.l.) for the highest shoreline formed during the Yoldia Sea and the Ancylus Lake stages in Finland. Areas covered by the llomantsi Ice Lake (A) (Vesajoki et al., 1986), the Saimaa-Sääminki Ice Lake (B) (Saarnisto, 1970; Eronen \& Haila, 1992; Hakulinen, 2009), the Pielinen Ice Lake (C) (Miettinen, 2002; Seppä et al., 2012), the Sotkamo Ice Lake (D) (Saarelainen \& Vanne, 1997), and various ice-dammed lakes in Northern Finland (E) (Johansson, 2005) are shaded with dark blue. Basemap (c) the National Land Survey of Finland. 
subaquatic areas in North Karelia and East Finland is more detailed in the present reconstruction. Also, as more data points from the Joensuu vicinity were introduced, the area is now characterized by more extensive subaquatic areas than the reconstruction by Eronen \& Haila (1992). There are also other prominent local differences between these two reconstructions. Among those is, for example, that the present reconstruction indicates more supraaquatic land in the Loppi region, highlands of Tammela and the vicinity of Sodankylä than the old one by Eronen \& Haila (1992). The western Finnish Lapland, on the other hand, is characterized by less supra-aquatic land than suggested by Eronen \& Haila (1992).

In general, the reconstruction shows that the highest shoreline of the Baltic Sea basin in Finland is $220 \mathrm{~m}$ a.s.l. in the Rovaniemi area (Vammavaara), which was formed during the Ancylus Lake stage (e.g. Saarnisto, 1981; Johansson, 2005). The highest shoreline of the Baltic Ice Lake lies at $163 \mathrm{~m}$ a.s.l., and this is observed at Hämeenlinna (Tullinkangas $162.2 \mathrm{~m}$ a.s.l.). The ca. $25 \mathrm{~m}$ drop of the Baltic Ice Lake to the Yoldia Sea level can be seen in many locations inside the Second Salpausselkä (e.g. Glückert, 1977). In the Loppi area, for example, the highest shoreline in delta formation of Väärä Vastamäki reaches $151.1 \mathrm{~m}$ a.s.l. whereas the top of the delta at Pikku-Punelia, located $4 \mathrm{~km}$ to NW from Väärä Vastamäki, lies at a level 122.9 m a.s.l. representing the highest shoreline of the Yoldia Sea stage.

\section{Conclusions and future prospects}

The present paper introduces the structure and application of the BSB shore displacement geodatabase called the Ancient Shoreline Database (ASD). The ASD was conceived in a way that it can be used to document shoreline and lake isolation data related to any of the shoreline stages of the $\mathrm{BSB}$. In this initial stage of the project, only information related to the maximum extension of the diachronous Litorina Sea and the highest shoreline in Finland were gathered and classified in the ASD. This information was then used to reconstruct the boundary between subaquatic and supra-aquatic areas, and areas covered by the Litorina Sea at 9000-7000 cal BP, as well as their isobases and gridded digital elevation models for the areas below and above the ancient shorelines.

The current paper presents the first version of the ASD and its usability in determining the main characteristics of ancient shorelines in Finland. The work accomplished here, i.e. gathering all available information, interpreting new observations of the Litorina Sea and the highest shoreline landforms and modelling of the ancient shorelines with TINbased interpolation, reveals that there is still room for improvement of the data quality and coverage, as well as for reconstructions of the ancient shorelines during different stages of the Baltic Sea basin in Finland. At present, 1625 data points are included in the ASD, of which about $42 \%$ and 48 $\%$ are related to the Litorina Sea shoreline and the highest shoreline, respectively, and the remaining ca. $10 \%$ represent either local ice lakes or have remained unidentified. The ASD includes available information from the literature as well as a collection of many new data points interpreted during the present study. Importantly, the ASD includes all the data points collected and not only those used in the TIN-based shoreline reconstructions in the present study.

One of the aims of the present work was to provide researchers an access to all available and carefully classified shoreline data, from which they could select the data they consider relevant in terms of their own shoreline reconstructions in geographically restricted areas, for example. The ASD will soon (December 2013) be available for researchers through the geological web data services provided by the Geological Survey of Finland (GTK). The ASD is intended to be updated at certain intervals with additional ancient shoreline observations provided by the scientific community. It could in the future be used to record all available shoreline information related, for example, to the Ancylus Lake stage or shorelines of the ancient ice lakes (e.g. Vesajoki et al., 1986; Saarelainen \& Vanne, 1997; Johansson, 2005) or great lakes in 
Finland (e.g. Saarnisto, 1970; 1971). For example, recording and classifying all available isolationstratigraphical information related to different stages of the Yoldia Sea, Ancylus Lake and Litorina Sea available in the literature would be most useful from the viewpoint of creating an up-to-date database for shoreline displacement curves in Finland. One additional future possibility is to combine the ASD information with that collected by Vassiljev et al. (2005) and Rosentau (2006) in Estonia, Svensson (1989) and Jakobsson et al. (2007) in Sweden, as well as other available information in the BSB region, in order to extend the reconstructions to the entire Baltic Sea basin.

\section{Acknowledgements}

The help and data contribution of the following persons is gratefully acknowledged: O. Breilin, A. Ikonen, P. Johansson, M. Larronmaa, J.-P. Mäkiaho, K. Mäkinen, J. Oksanen, N. Putkinen, O. Ristaniemi, H. Rönty, J. Saarelainen, M. Saarnisto, J. Vanne, J. Vassiljev and T. Väänänen.

\section{References}

Aario, L. 1935. Die Postglazialen Niveauvershiebungen im mittleren Uusimaa mit Berücksichtigung ihrer Beziehungen zu steinzeitlichen wohnpläze. Annales Academiae Scientiarum Fennicae A 44, 1-161.

Andrén, E., Andrén, T. \& Sohlenius, G. 2000. The Holocene history of the southwestern Baltic Sea as reflected in a sediment core from the Bornholm Basin. Boreas 29, 233250.

Aurola, E. 1938. Die Postglaziale Entwicklung Des Südwestlichen Finlands. Bulletin de la Commision géologique de Finlande 121, 7-166.

Bellian, J.A., Kerans, C. \& Jenette, D.C. 2005. Digital outcrop models: applications of terrestrial scanning lidar technology in stratigraphic modeling. Journal of Sedimentary Research 75, 166-176.

Björck, S. 1995. A review of the history of the Baltic Sea, 13.08.0 ka BP. Quaternary International 27, 19-40.

Burrough, P. \& McDonnell, R. 1998. Principles of Geographical Information Systems - Spatial Information Systems and Geostatistics. Oxford University Press, UK, $333 \mathrm{p}$.

Chen, Z., Devereux, B., Gao, B. \& Amable, G. 2012. Upwardfusion urban DTM generating method using airborne Lidar data. ISPRS Journal of Photogrammetry and Remote Sensing 72, 121-130.
De Geer, G. 1890. Om Skandinaviens nivåförändringar under quartärtiden. Geologiska Föreningens i Stockholm Förhandlingar 12, 61-110.

Donner, J. 1995. The Quaternary History of Scandinavia. Cambridge University Press, Cambridge, 200 p.

Dowling, T.P.F., Alexanderson, H. \& Möller, P. 2013. The new high-resolution LiDAR digital height model (' $\mathrm{Ny}$ Nationell Höjdmodell') and its application to Swedish Quaternary geomorphology. GFF, 135, 145-151.

Eronen, M. 1974. The history of the Litorina Sea and associated Holocene events. Societas Scientiarum Fennica, Commentationes Physico Mathematicae 44, 79-195.

Eronen, M. 1992. Evolution of the Baltic Sea. In: Alalammi, P. (ed) Atlas of Finland, Folio 123-126: Geology. National Board of Survey \& Geographical Society of Finland, Helsinki, 15-18.

Eronen, M. \& Haila, H. 1992. The main ancient shorelines. In: Alalammi, P. (ed) Atlas of Finland, Folio 123-126: Geology. National Board of Survey \& Geographical Society of Finland, Helsinki, 17.

Eronen, M., Glückert, G., van de Plassche, O., van der Plicht, J., Rajala, P. \& Rantala, P. 1993. The postglacial radiocarbon-dated shoreline data in Finland for the Nordic Data Base of Land Uplift and Shorelines. Swedish Nuclear Power Inspectorate (SKi), Project NKS/KAN 3, subproject 3.2.4.2, 1992-93, Stencil. 1-40.

Eronen, M., Glückert, G., Hatakka, L., Plassche, O., van de Plicht, J. \& Rantala, P. 2001. Rates of Holocene isostatic uplift and relative sea-level lowering of the Baltic in SW Finland based on studies of isolation contacts. Boreas 30, $17-30$.

Fairbanks, R.G. 1989. A 17,000-year glacio-eustatic sea level record: influence of glacial melting rates on the Younger Dryas event and deep-ocean circulation. Nature 342, 637642.

Fleeger, G.M., Grote, T., Straffin, E. \& Szabo, J.P. 2011. Quaternary geology of northwestern Pennsylvania. In: Ruffolo, R.M. \& Ciampaglio, C.N. (eds.) From the Shield to the Sea: Geological Field Trips from the 2011 Joint Meeting of the GSA Northeastern and North-Central Sections. Geological Society of America, Field Guide 20, 87-109.

Fromm, E. 1965. Beskrivning till jordartskarta över Nordbottens län nedarför Lappmarkgränsen. Sveriges Geologiska Undersökning 39, 236 p.

Glückert, G. 1976. Post-Glacial Shore-Level Displacement of the Baltic in SW Finland. Annales Academiae Scientierum Fennicae, Series A. III, Geologica - Geographica 118, 3233.

Glückert, G. 1977. Itämeren korkeimman rannan kehityksestä Salpausselkävyöhykkeessä Lohjan-Karkkilan-Lopen alueella. [Highest coastline of the Baltic in the Salpausselkä belt, the area of Lohja-Karkkila-Loppi, SW Finland]. Publication of the Department of Quaternary Geology, 
University of Turku 32, 1-22.

Glückert, G. 1978. Östersjöns postglaciala strandförskjutning och skogens historia på Åland. Publication of the Department of Quaternary Geology, University of Turku 34, 1-106.

Glückert, G. 1989. Itämeren rannansiirtyminen Etelä- ja Keski-Pohjanmaalla Ancylusjärvi- ja Litorinamerivaiheiden (9000 vuoden) aikana. Publication of the Department of Quaternary Geology, University of Turku 64, 1-14.

Glückert, G., Rantala, P. \& Ristaniemi, O. 1993. Itämeren jääkauden jälkeinen rannansiirtyminen Pohjanmaalla. Abstract: Postglacial shore-level displacement of the Baltic in Ostrobothnia. Publication of the Department of Quaternary Geology, University of Turku 77, 5-36.

Hakulinen, M. 2009. Saimaan jääjärvet, sininen hetki - yli 10 000 vuotta sitten. Geomatti Oy, 92 p.

Haneberg, W.C., Cole, W.F. \& Kasali, G. 2009. High-resolution LiDAR-based landslide hazard mapping and modeling, UCSF Parnassus Campus, San Francisco, USA. Bulletin of Engineering Geology and the Environment 68, 263276.

Hellaakoski, A. 1934. Die Eisstauseen des Saimaa-Gebietes. Fennia 59, 1-102.

Hyyppä, E. 1937. Post-glacial changes of shore-Line in South Finland. Bulletin de la Commision géologique de Finlande $120,7-225$.

Ikävalko, O., Jarva, J., Ojalainen, J., Ojala, A. \& Tarvainen, T. 2011. Opportunities for urban geology in Finland: mapping, databases and data processing for land use planning and construction. Geological Survey of Finland, Special Paper 49, 197-204.

Jakobsson, M., Björck, S., Alm, G., Andrén, T., Lindeberg, G. \& Svensson, N.-O. 2007. Reconstructing the Younger Dryas ice dammed lake in the Baltic Basin: Bathymetry, area and volume. Global and Planetary Change 57, 355370.

Jenness, J. 2013. DEM Surface Tools for ArcGIS (surface_ area.exe). Jenness Enterprises. Available at: http://www. jennessent.com/arcgis/surface_area.htm

Johansson, P. 2005. Jääjärvet. In: Johansson, P. \& Kujansuu, R. (eds.) Pohjois-Suomen maaperä. [Quaternary deposits of Northern Finland]. Geologian tutkimuskeskus, Espoo, 127-149.

Johansson, P. \& Kujansuu, R. (eds.) 2005. Pohjois-Suomen maaperä. [Quaternary deposits of Northern Finland]. Geologian tutkimuskeskus, Espoo, 236 p.

Kakkuri, J. 2012. Fennoscandian land uplift: Past, present and future. In: Haapala, I. (ed.) From the Earth's core to outer space. Springer, Dordrecht, 127-136.

Kurimo, H. 1979. Late-glacial ice flows, deglaciation and associated events in northern Kainuu and Peräpohjola, North-East Finland. A glacial morphological study. Joensuun korkeakoulun julkaisuja, Serie B II, 1-115.

Leverington, D.W., Teller, J.T. \& Mann, J.D. 2002. A GIS method for reconstruction of landscapes from isobase data and modern topography. Computers \& Geoscience 28, 631-639.

Meng, X., Currit, N. \& Zhao, K. 2010. Ground filtering algorithms for airborne LiDAR data: a review of critical issues. Remote Sensing 2, 833-860.

Miettinen, A., Eronen, M. \& Hyvärinen, H. 1999. Land uplift and relative sea-level changes in the Loviisa area, southeastern Finland, during the last 8000 years. Posiva Report 99-28, 1-26.

Miettinen, A. 2002. Relative sea level changes in the eastern part of the Gulf of Finland during the last 8000 Years. Annales Academiae Sciantiarum Fennicae Geologica Geographica 162, 5-91.

Mäkiaho, J.-P. 2007. Estimation of ancient and future shoreline positions in the vicinity of Olkiluoto, an island on the western coast of Finland: the difference between grid and TIN based GIS-approaches. Palaeogeography, Palaeoclimatology, Palaeoecology 252, 514-529.

Mäkiaho, J.-P., 2009. Helsinki - Itämeren tytär: paikkatietomenetelmät rannansiirtymistutkimuksessa. Terra 121, 317.

Mäkinen, K., Teeriaho, J., Rönty, H., Rauhaniemi, T. \& Sahala, L. 2011. Valtakunnallisesti arvokkaat tuuli- ja rantakerrostumat. [Nationally valuable aeolian and littoral deposits]. Suomen ympäristö 32, Helsinki: Ympäristöministeriö, $185 \mathrm{p}$.

Nenonen, K., Vanne, J. \& Laaksonen, H. 2010. Laserkeilaus uusi menetelmä geologisen kartoitukseen ja tutkimukseen. [Airborne laser scanning - a new method to geological mapping and research]. Geologi 62, 62-69.

Ojala, A.E.K., Heinsalu, A., Saarnisto, M. \& Tiljander, M. 2005. Annually laminated sediments date the drainage of the Ancylus Lake and early Holocene shoreline displacement in central Finland. Quaternary International 130, 63-73.

Oksanen, J. 1998. Itämeren ylin ranta eteläisessä Suomessa. Pro gradu, Department of geography, University of Helsinki, $90 \mathrm{p}$.

Oksanen, J. \& Sarjakoski, T. 2006. Uncovering the statistical and spatial characteristics of fine toposcale DEM error. International Journal of Geographical Information Science 20, 345-369.

Palmu, J.-P. 2011. Collection, management and distribution of data on surficial deposits. Geological Survey of Finland, Special Paper 49, 345-348.

Ramsay, W. 1924. On relations between crustal movements and variations of sea-level during the Late Quaternary time, especially in Fennoscandia. Fennia 44, 1-39.

Ramsay, W. 1931. Material zur Kenntnis der Spätglazialen Niveauverschiebungen in Finnland. Fennia 54, 1-145.

Reimer, P.J., Baillie, M.G.L., Bard, E., Bayliss, A., Beck, J.W., Blackwell, P.G., Bronk Ramsey, C., Buck, C.E., Burr, G.S., Edwards, R.L., Friedrich, M., Grootes, P.M., Guilderson, 
T.P., Hajdas, I., Heaton, T.J., Hogg, A.G., Hughen, K.A., Kaiser, K.F., Kromer, B., McCormac, F.G., Manning, S.W., Reimer, R.W., Richards, D.A., Southon, J.R., Talamo, S., Turney, C.M.S., van der Plicht, J., \& Weyhenmeyer, C.E. 2009. IntCal09 and Marine09 radiocarbon age calibration curves, 0-50,000 years cal BP. Radiocarbon 51, 11111150 .

Ristaniemi, O. 1987. Itämeren korkein ranta ja Ancylusraja sekä Muinais-Päijänne Keski-Suomessa. [The highest shore and Ancylus limit of the Baltic Sea and the Ancient Lake Päijänne in Central Finland]. Publication of University of Turku, Series C 59, 1-102.

Ristaniemi, O. \& Glückert, G. 1988. Ancylus- ja Litorinatransgressiot Lounais-Suomessa. In: Lappalainen, V. \& Papunen, H. (eds.) Tutkimuksia geologian alalta. Publication of University of Turku, Series C 67, 129-145.

Rosentau, A. 2006. Development of proglacial lakes in Estonia. $\mathrm{PhD}$ thesis, Dissertationes Geologicae Universitatis Tartuensis $18,113 \mathrm{p}$.

Rudeberg, G. 1925. Om nivåförändringarna i sydvästra Finland. Geografiska Annaler 4, 343-352.

Saarelainen, J. \& Vanne, J. 1997. Sotkamon jääjärvi. [Sotkamo Ice Lake]. Terra 109, 25-38.

Saarnisto, M. 1970. The late Weichselian and Flandrian History of the Saimaa Lake Complex. Societas Scientiarum Fennica, Commentationes Physico-Mathematicae 37, 1-107.

Saarnisto, M. 1971. The upper limit of the Flandrian transgression of Lake Päijänne. Societas Scientiarum Fennica, Commentationes Physico-Mathematicae 41, 149170.

Saarnisto, M. 1981. Holocene emergence history and stratigraphy in the area north of the Gulf of Bothnia. Annales Academiae Scientiarum Fennicae, Series A. III, Geologica - Geographica 130, 1-42.

Saarnisto, M. 1982. Ice retreat and the Baltic Ice Lake in the Salpausselkä zone between Lake Päijänne and Lake Saimaa. Annales Academiae Scientiarum Fennicae, Series A. III, Geologica - Geographica 134, 61-79.

Sauramo, M. 1928. Über die Spätglazialen Niveauverschiebungen in Nordkarelien, Finland. Bulletin de la Commission géologique de Finlande 80, 1-41.

Schulz, W.H. 2007. Landslide susceptibility revealed by LIDAR imagery and historical records, Seattle, Washington. Engineering Geology 89, 67-87.

Seppä, H., Tikkanen, M., Mäkiaho, J.-P. 2012. Tilting of Lake Pielinen, eastern Finland - an example of extreme transgressions and regressions caused by differential postglacial isostatic uplift. Estonian Journal of Earth Science 61, 149-161.

Streutker, D.R. \& Glenn, N.F. 2006. LiDAR measurement of sagebrush steppe vegetation heights. Remote Sensing of Environment 102, 135-145.

Svensson, N.-O. 1989. Late Weichselian and Early Holocene shore displacement in the central Baltic, based on stratigraphical and morphological records from eastern Småland and Gotland, Sweden. LUNQUA, PhD Thesis $25,195 \mathrm{p}$.

Tikkanen, M. \& Oksanen, J. 2002. Late Weichselian and Holocene shore displacement history of the Baltic Sea in Finland. Fennia 180, 9-20.

Ukkonen, P. 2002. The early history of seals in the northern Baltic. Annales Zoologi Fennici 39, 187-207.

Vassiljev J., Saarse, L. \& Miidel, A. 2005. Simulation of proglacial lake shore displacement in Estonia. Geological Quarterly 49, 253-262.

Vesajoki, H., Eronen, M. \& Zetterberg, P. 1986. Monivaiheinen Ilomantsin jääärvi. [The various phases of development of the Ilomantsi Ice Lake, eastern Finland]. Geologi 38, 111-115.

Vuori, S., Aatos, S. \& Tuusjärvi, M. 2011. Geological resource accounting and associated research. Geological Survey of Finland, Special Paper 49, 115-120.

Yang, Z. \& Teller, J.T. 2012. Using LiDAR Digital Elevation Model data to map Lake Agassiz beaches, measure their isostatically-induced gradients, and estimate their ages. Quaternary International 260, 32-42.

Åberg, A. 2013a. Ylin ranta Suomessa. Department of geosciences and geography, University of Helsinki, Master's thesis, $84 \mathrm{p}$.

Åberg, S. 2013b. Litorinameren korkein ranta Suomessa. Department of geosciences and geography, University of Helsinki, Master's thesis, 79 p.

\section{Appendix 1.}

Description of the dataset feature properties in the ASD. (*Domain fields with coded values).

\section{Ancient Shoreline Database (ASD)}

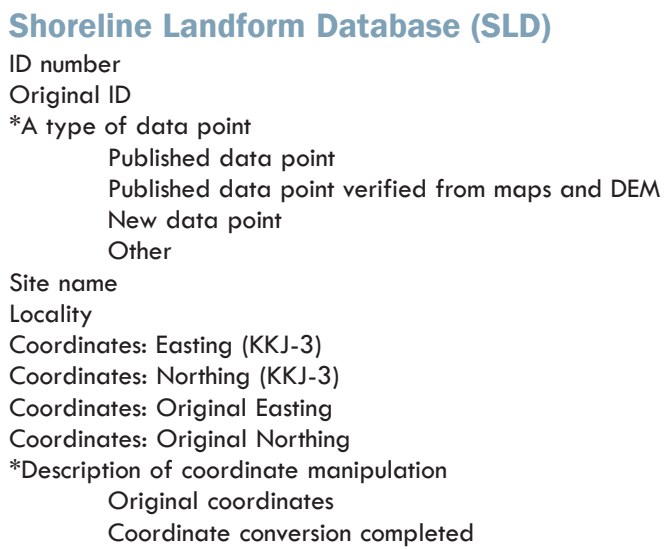


Corrected coordinates

Missing coordinates

More detailed coordinates

Other reason

Text: additional description of coordinate manipulation

*Landform type

Delta surface

Beach ridge

Delta and beach ridge

Cliff and shore terrace

Stone belt

Lake rampart

Moraine calotte and a washed hillside

Outlet channel and delta surface (local ice lake)

Other

Esker Top

Shoreline altitude (mean)

Shoreline altitude (minimum)

Shoreline altitude (maximum)

Shoreline altitude (as in original reference)

* Description of altitude manipulation

Original altitude

Corrected altitude

Missing altitude information

More detailed altitude

Other reason

Shoreline stage index (as proposed by original investigator)

*Highest shoreline

Yes

No

*Shoreline stage index (interpreted in this study)

Baltic Ice Lake

Yoldia Sea

Ancylus Lake (early stage and maximum transgression)

Ancylus Lake (late stage)

Litorina Sea (early stage)

Litorina Sea (transgression maximum)

Litorina Sea (late stage)

Local ice lake

Ancient lake

Anthropogenically drained lake

Other or undetermined

A study year (original)

Principal investigator (original)

Reference

*Reliability classification

Class 1

Class 2

Class 3

Class 4

Class 5

Other notes

Shoreline altitude (dm a.s.l.)

*DEM used to validate the shoreline altitude laserDEM

DEM 25

DEM 10

Other

*Data point used in the reconstruction by Åberg 2013

Yes

No
Isolation Database (ISD)

ID number

Original ID

Site name

Locality

Coordinates: Easting (KKJ-3)

Coordinates: Northing (KKJ-3)

Coordinates: Original Easting

Coordinates: Original Northing

*Description of coordinate manipulation

Original coordinates

Coordinate conversion completed

Corrected coordinates

Missing coordinates

More detailed coordinates

Other reason

Text: additional description of coordinate manipulation

*Site type

Lake

Mire

Other

Current surface altitude of lake/mire (m a.s.l.)

Threshold altitude of isolation ( $m$ a.s.l.)

Radiocarbon age of isolation

Radiocarbon sample code

Radiocarbon age error (years +/-)

Calibrated radiocarbon age (BC/AD): MEDIAN (2 sigma)

Calibrated radiocarbon age (BC/AD): MINIMUM (2 sigma)

Calibrated radiocarbon age (BC/AD): MAXIMUM (2 sigma)

Shoreline stage index (as proposed by original investigator)

*Highest shoreline

Yes

No

*Shoreline stage index (interpreted in this study)

Baltic Ice Lake

Yoldia Sea

Ancylus Lake (early stage and maximum transgression)

Ancylus Lake (late stage)

Litorina Sea (early stage)

Litorina Sea (transgression maximum)

Litorina Sea (late stage)

Local ice lake

Ancient lake

Anthropogenically drained lake

Other or undetermined

A study year (original)

Principal investigator (original)

Reference

*Reliability classification

Class 1

Class 2

Class 3

Class 4

Class 5

Other notes

Current surface altitude of lake/mire (dm a.s.l.)

*DEM used to validate the current surface altitude of lake/mire laserDEM

DEM25

DEM 10

Other

*Data point used in the reconstruction by Åberg 2013

Yes

No 